\title{
Human-rights court to rule on fertility-treatment ban
}

\author{
Costa Rica, the only country that forbids in vitro fertilization, may have to lift the prohibition.
}

\section{Michele Catanzaro}

14 September 2012

The Inter-American Court of Human Rights is set to decide whether Costa Rica, the only country that completely prohibits in vitro fertilization (IVF), has infringed basic rights with its ban. The tribunal — which is based in the Costa Rican capital of San José but rules on human-rights violations throughout Central and South America - met last week to hear a case brought by affected couples against Costa Rica.

The decision, expected in the next few months, may oblige Costa Rica to lift the ban and regulate IVF. But scientists are concerned that if the prohibition is upheld, it will set a bad precedent for laws related to health, including one that would lift a ban on experiments involving humans, such as drug trials, that was first brought before the country's parliament in 2011.

Although several other countries have no regulation for IVF, or don't actually offer access

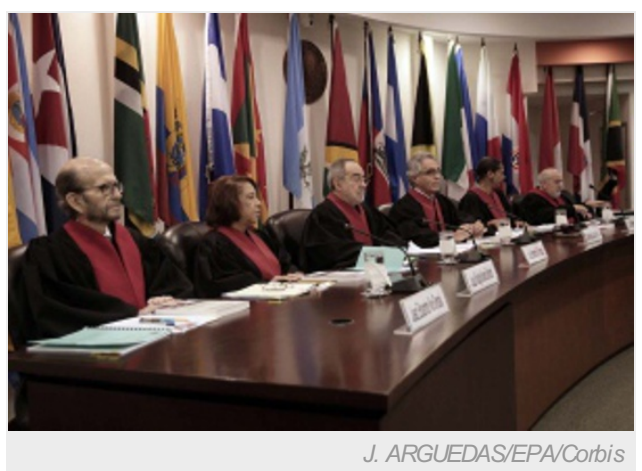

Judges heard the case against the Costa Rican ban on in vitro fertilization at the Inter-American Court of Human Rights last week. to fertility therapies, Costa Rica is the only nation known to have a total ban, says Sheryl Vanderpoel a spokeswoman for the Reproductive Health and Research Department at the World Health Organization.

IVF was legal in Costa Rica between 1995 and 2000, but the relevant law was revoked by the country's Constitutional Court on the basis of the right to life expressed in article 21 of the Costa Rican constitution and article 4 of the American Convention on Human Rights.

"The state makes a mistaken interpretation of the right to life, treating a fertilized egg as a person: in fact, not all embryos result in a newborn," says Gerardo Escalante, director of the Costa Rican Institute of Fertility in San José, the only clinic that provided IVF in Costa Rica before the prohibition. "The current situation is discriminating against people with reproductive disability, especially those without enough money to go abroad for treatment."

\section{Long wait}

In January 2001, nine infertile couples presented a petition against the ban to the Inter-American Commission on Human Rights. Ten years later, the commission issued a dossier stating that Costa Rica has infringed the rights to privacy, family life and non-discrimination, articles 11,17 , and 24 of the American Convention on Human Rights. This pronouncement led to last week's trial. 
Anthony Caruso, a reproductive endocrinologist at the Alexian Brothers Medical Center in Chicago, Illinois. "There is no way to do IVF without losing embryos."

Gabriel Macaya Trejos, director of the Costa Rican National Academy of Sciences in San Pedro, says that most scientists are in favour of IVF, "but those opposing are more vocal, and mask religious convictions with pseudo-scientific arguments".

Macaya worries that a win for the opponents of IVF will make it more difficult to pass a law on research involving humans. In January 2010 , the Costa Rican Constitutional Court suspended all human-based experiments in the country until a specific law on the issue could be approved. Legislation was finally put forward in February 2011, but the discussion is being delayed due to objections from members of parliament. "The Costa Rican system has proved incapable of reaching consensus on health-related issues," says Macaya.

Nature | doi:10.1038/nature.2012.11417

Nature ISSN0028-0836 ESSN 1476-4687

\section{SPRINGER NATURE}

